\title{
ASPH Positive
}

National Cancer Institute

\section{Source}

National Cancer Institute. ASPH Positive. NCI Thesaurus. Code C163005.

An indication that ASPH expression has been detected in a sample. 